\title{
The Effect of High Temperature on $\alpha$ - Amylase Enzyme Activity in the Germination of Several Rice Varieties (Oryza sativa L.)
}

\author{
Afrima Sari, Aswaldi Anwar, and Nalwida Rozen \\ Department of Agrotechnology, Faculty of Agriculture, Andalas University, Padang, West Sumatra, 25163, Indonesia
}

Article Info

Received:

26 February 2021

Accepted:

28 February 2021

Published:

10 March 2021

Competing Interest:

The authors have declared that no competing interest exists.

Corresponding Author: Afrima Sari, Department of Agrotechnology, Faculty of Agriculture, Andalas University, Padang, West Sumatra, 25163, Indonesia

Email: afrimasari@agr.unand.ac.id

(C) 2021 The Authors. This is an open access article under the CC BY license.

\begin{abstract}
High temperatures can affect plant morphophysiological changes and enzyme denaturation that can interfere with the germination process. One of the enzymes in rice germination is the amylase enzyme. This research aims to study temperature changes on the $\alpha$-amylase enzyme activity of several rice varieties germination. The research applies Factorial Experiment in Completely Random Design, where the first factor is four levels of rice varieties, Anak Daro, Batang Piaman, Cisokan, and Inpari 30 . The second factor is temperature level, $28^{\circ} \mathrm{C}$, $32^{\circ} \mathrm{C}, 36^{\circ} \mathrm{C}, 40^{\circ} \mathrm{C}, 44^{\circ} \mathrm{C}$ and $48^{\circ} \mathrm{C}$. Results showed that the activity of the $\alpha-$ amylase enzymes of the four varieties increased when the temperature increased to reach the optimal temperature, and denaturation began to occur above that temperature. The highest enzyme activity of $\alpha$-amylase of Anak Daro, Cisokan and Inpari 30 varieties at $48^{\circ} \mathrm{C}$ is 0,14 micromol, 0,365 micromol dan 0,191 micromol. The activity of the $\alpha$-amylase enzyme of Batang Piaman at $40^{\circ} \mathrm{C}$ is 0,237 micromol, and at $48^{\circ} \mathrm{C}$, the activity of the $\alpha$-amylase enzyme decreases to 0,138 micromols. The variation in the activity of $\alpha$-amylase enzymes in the four varieties is probably due to genetic differences and sucrose content.
\end{abstract}

Keywords: abiotic stress, denaturation, enzym, germination, high temperature 


\section{Introduction}

Rice (Oryza sativa L.) is a staple food for more than $50 \%$ of the world's population and almost $80 \%$ in Indonesia. However, abiotic stresses (especially high temperature) are among the major causes of low yield. Germination will determine the success of plant life in the next stage. According to Yoshida (1978), rice germination's optimum temperature is $18-40^{\circ} \mathrm{C}$, where if the temperature increases, cell damage, and enzyme denaturation occur (Soepandi, 2014). High temperatures make inactivation of enzymes in chloroplasts and mitochondria, inhibit protein synthesis, protein degradation, and loss of membrane integrity (Taiz and Zeiger, 2006). The ability of plants to adapt to high-temperature stress varies between genotypes. The mechanism of plants' adaptation can also be through the decomposition of starch through the mitochondria's energy (Tanaka et al ., 2009).

Seed germination begins with imbibition, activation of growth hormones and enzymes, initiation of embryonic growth, and radicles and plumules' emergence. One of the enzymes in rice germination is the amylase enzyme. The $\alpha$-amylase enzyme functions to solve amylose and amylopectin to maltose and glucose. This enzyme does not exist (non-existent) in dry seeds but only made later at the beginning of seed germination (early stage of germination) by gibberellins (GA3), while the $\beta$-amylase enzyme already exists from the beginning (pre-exist) in scutellum and aleuron layers in seeds that are still dry (Kamil, 1982). The enzyme activity of $\alpha$-amylase also affects the length of the hypocotyl sprouts. Darmayanti et al. (2013) report that mung bean sprouts' cotyledons showed enzyme activity $\alpha$-amylase, which is highest at the cotyledon sprouts the high of hypocotyl reached $1 \mathrm{~cm}$ and the activity of the enzyme $\alpha$-amylase lowest for the cotyledon sprouts at the time hypocotyl height reaches $9 \mathrm{~cm}$.

Another thing is the genetic factors of each different variety through the emergent phenotypes. Molecularly, the amylase solving by amino acid residues on the active side of enzymes can interact with glucose residues in amylose and amylopectin (Matsuura, 1999 Cit Nangin dan Aji, 2015). Differences in rice genotypes' ability for the four varieties tested need further research at the molecular stage. The resistance genes found in Anak Daro and Inpari 30 varieties can still grow at $40^{\circ} \mathrm{C}$ because there are no reports analyze resistance genes against hightemperature stress. This research aims to study temperature changes on the $\alpha$-amylase enzyme activity of several rice varieties germination: the basic science in selecting high-temperature-tolerant plants.

\section{Materials and Methods}

\section{A. Plant Material and Time of Research}

Plant material are Anak Daro, Batang Piaman, Cisokan and Inpari 30 (Figure 1). Anak Daro, Batang Piaman, and Cisokan varieties are superior local varieties of West Sumatra with a pera rice texture. Inpari 30 is a national variety with a fluffier rice texture suitable for planting in lowland irrigation to 400 meters above sea level. This research was conducted at Seed Technology and Plant Physiology Laboratory, Andalas University and Chemistry Laboratory, University of Padang.

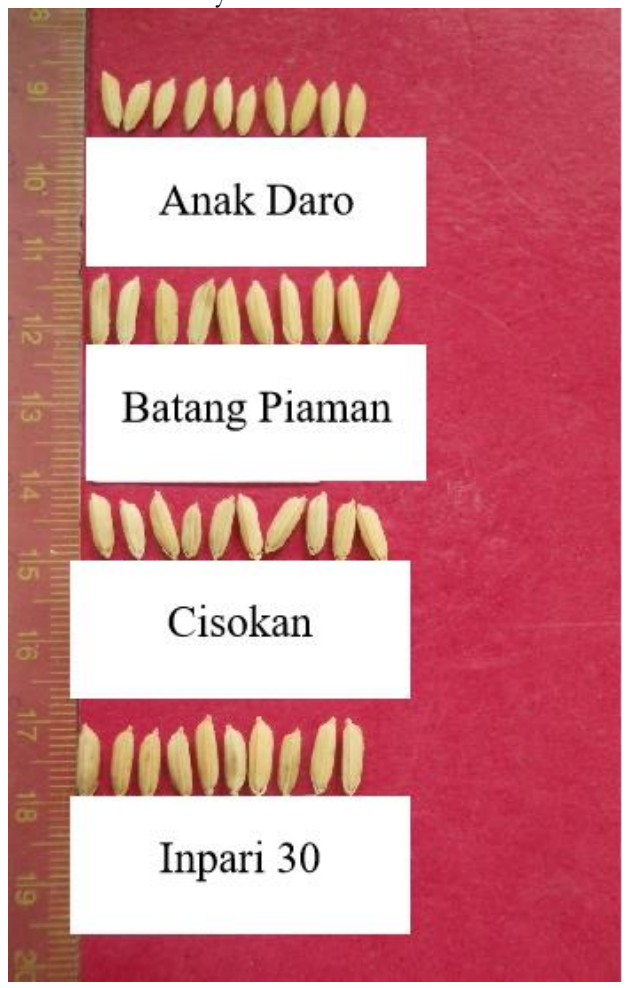

Figure 1. Morphological of Four Rice Seed Varieties 


\section{B. Experimental Details}

The research applies Factorial Experiment in Completely Random Design, where the first factor is four levels of rice varieties, Anak Daro, Batang Piaman, Cisokan, and Inpari 30. The second factor is temperature level, $28^{\circ} \mathrm{C}, 32^{\circ} \mathrm{C}, 36^{\circ} \mathrm{C}, 40^{\circ} \mathrm{C}, 44^{\circ} \mathrm{C}$ and $48^{\circ} \mathrm{C}$.

\section{Enzym activity}

Enzym activity shows how much maltose release due to the starch substrate's reaction with the amylase enzyme. The higher enzyme activity from the seed then maltose produced also increases so that maltose in seeds has germinated more than the seeds in a dry state (Ramansyah, 2004). Testing the activity of amylase enzymes in 2-day-old sprouts; according to Widayati (1992) cit Sadjad et al., 1999, the biochemical value of seeds is based on the content of the amylase enzyme used as a potential viability standard was 1-2 days old sprouts. Amylase enzyme activity measure by the amount of maltose formed after the starch substrate incubates with the amylase enzyme. The absorbance value was measured using a spectrophotometer at a wavelength of $560 \mathrm{~nm}$. One unit of $\alpha$-amylase activity is the number of enzymes that can produce $1 \mu \mathrm{g}$ per minute sugar per $\mathrm{ml}$ of the enzyme process (Naiola, 2008). Samples were weighed as much as 2.5 grams from each treatment temperature then mashed with mortar. Then, the sample is added to the $\mathrm{pH} 5.5$ acetate buffer as much as $12.5 \mathrm{ml}$ and left for 30 minutes, which serves to maintain the sample $\mathrm{pH}$. The sample was then filtered with Whatman paper and centrifuged at $1500 \mathrm{rpm}$ for 30 minutes; then, supernatant activity tests taken.

\section{Statistical Analysis}

The extraction enzyme serves as a catalyst that will accelerate the hydrolysis rate of starch; $1 \mathrm{ml}$ enzyme extraction results were added to $1 \mathrm{ml}$ of $1 \%$ starch substrate solution and then incubated for 3 minutes at $30^{\circ} \mathrm{C}$. Then, add $1 \mathrm{ml}$ of DNS (3.5 dinitro salicylic acid), heat it to $40^{\circ} \mathrm{C}$, and then cool quickly in a measuring cup given ice cubes. DNS reagents can detect reducing sugars in the form of disaccharides in maltose from the hydrolysis of starch substrates by the amylase enzyme.

A spectrophotometer measures absorption at a wavelength of $560 \mathrm{~nm}$. $\alpha$-amylase enzyme activity calculation is done by first making a standard curve that already contains data in ppm concentration and absorbance, which will produce a linear equation. The absorbance value of a standard solution produced using a spectrophotometer is the y-axis, while the $\mathrm{x}$ axis is the concentration of each sample. The next step is $\alpha$-amylase enzyme activity calculation using the formula:

The activity of $\alpha$-amylase enzyme $=\mathrm{C} \times \frac{1}{\tau} \times 1$ unit

Note:
$\mathrm{C}=$ Concentration of maltose per $\mathrm{ml}$ extract enzyme (micromol)

$\mathrm{T}=$ Incubation time (minutes)

One unit activity of $\alpha$-amylase enzyme: The enzyme activity value needed to release one micromol maltose per minute per $\mathrm{ml}$ of the enzyme.

\section{Results and Discussion}

The enzyme activities have different units depending on the description and testing method (Wahyuni, 2015). $\alpha$-amylase enzyme activity in micromol units shown in Figure 2 below.

The activity of enzymes optimally at $48^{\circ} \mathrm{C}$ (Wirahadikusumah, 1989). Batang Piaman $\alpha$-amylase enzyme activity optimally at temperatures of $40^{\circ} \mathrm{C}$, when the temperature increases, enzyme activity decreases, or denaturation occurs faster than the other varieties. Salisbury and Ross (1995) revealed that high temperatures could break hydrogen bonds and cause denaturation. The $\alpha$-amylase enzyme is composed of proteins and equipped with calcium ions marked by blue spheres and chloride ions marked by yellow fields. Calcium ions act as allostery stabilizers and activators (some enzymes can bind to other substrates when attached to a specific substrate ). The enzyme $\alpha$ amylase is calcium metalloenzymes to not function in the absence of calcium ions (Souza et al., 2010 cit Wahyuni, 2015 ).

$\alpha$-amylase is one of the enzymes involved in the first committed step for degradation of reserve starch, and activation of $\alpha$-amylase by high temperature is a crucial trigger for grain chalkiness and that its suppression is a potential strategy for ameliorating grain damage from global warming (Hakata et al., 2012). According to Soepandi (2014), calcium ion $(\mathrm{Ca} 2+)$ in the cytoplasm has increased in hightemperature, but the excess $\mathrm{Ca} 2+$ released into the cytoplasm causes the high $\mathrm{Ca} 2+$ in the cytoplasm in a long time will be toxic. The $\alpha$-amylase enzyme activity increases with increasing temperature because the active side can bind many substrates to reach its optimum temperature. However, the temperature gets higher; then, enzyme damage will occur.

Soepandi (2014) also reports differences in activity amylase enzymes in four varieties due to genetic variations and the straightforward sugar content. However, the genetic information and sugar content on these four varieties are not available, so we need next research in molecular. Glucose metabolism is a central metabolism compared to others. Bewley and Black (1985) Cit Sari (2004) explains whether monosaccharide sugar production increases the speed of transport or excessive use by embryos, then the sugar will accumulate in the endosperm. This sugar accumulation will be a useful trigger to stop the amylase enzyme production further; thus, the amylase enzyme will not be produced continuously but will be activated if needed. 

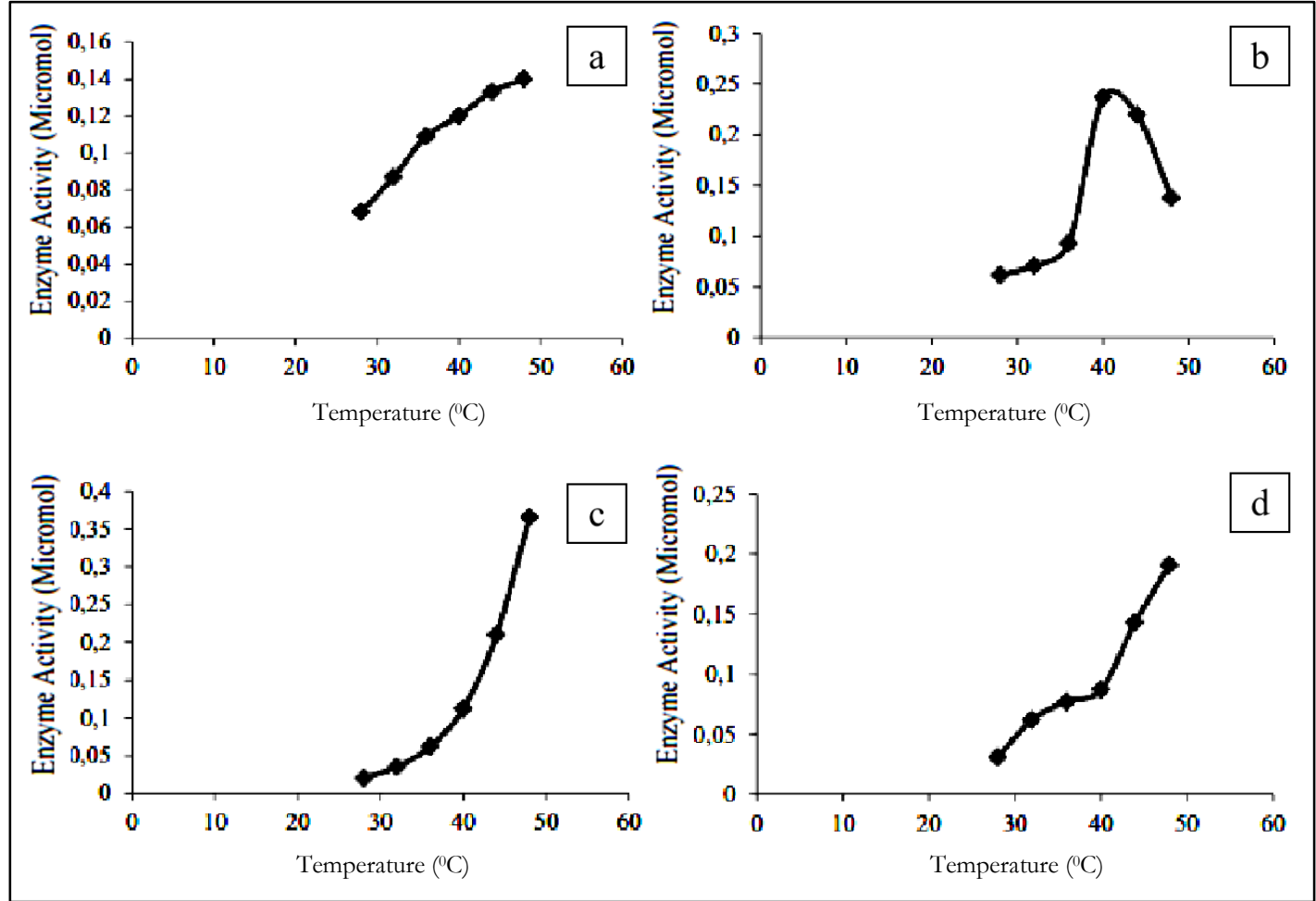

Figure 2. $\alpha$-amylase enzyme activity of varieties (a) Anak Daro (b) Batang Piaman (c) Cisokan (d) Inpari 30

Salisbury and Ross (1995) also revealed that at certain temperatures, some enzymes optimal function while others do not, and in general, enzymes' reactions will increase with temperature increases from $0^{\circ} \mathrm{C}$ to $35^{\circ} \mathrm{C}$ or $40^{\circ} \mathrm{C}$. Temperatures above $40^{\circ} \mathrm{C}$ cause denaturation of most plant enzymes to proceed very quickly, so that at high temperatures, there are no active catalysts to reduce the activation energy and insufficient availability of substrate molecules with sufficient strength to react without catalysts.

High-temperature tolerant rice genotypes showed more robust root activity, more active antioxidant defense systems on leaves, higher ATPase activity on seeds, and lower leaf temperatures than high temperature-sensitive rice genotypes (Ying et al.,2008). These results indicate that high-temperature tolerant rice genotypes reduce heat stress by increasing protective enzymes' activity against antioxidant systems to release free radicals in plants.

\section{Conclusions}

Enzyme activity of various varieties increases each optimal temperature rise, and denaturation begins to occur above that temperature. The enzyme activity of $\alpha$ amylase varieties of Anak Daro, Cisokan, and Inpari 30 was optimal at $48^{\circ} \mathrm{C}$, while the Batang Piaman variety was at $40^{\circ} \mathrm{C}$.

\section{References}

[1] Darmayanti, W., I. Suntoro dan Herpratiwi. 2013. Isolation of the $\alpha$-amylase enzyme characterization activity in white soybean and green bean sprouts under magnetic fields' influence. FKIP Unila : 1-7
[2] Hakata, M., M. Kuroda, T. Miyashita, T. Yamaguchi, M. Kojima, H. Sakakibara, T. Mitsui, and H.Yamakawa. 2012. Suppression of a-amylase genes improves quality of rice grain ripened under high temperature. Plant Biotechnology Journal (2012) 10, pp. 1110-1117.

[3] Kamil, J. 1982. Seed Technology Benih I. Penerbit Angkasa. Bandung. 95-105.

[4] Macovei, A., B. Garg, S. Raikwar, A. Balestrazzi. D. Carbonera, J. F. J. Bremont, S. S. Gill, and N. Tuteja. 2014. Synergistic exposure of ice seeds toNaiola, E. 2008. Amolithic microbes in roomie and laru from Timor Island, East Nusa Tenggara. Jurnal Biodiversitas. 9 (3) : 165-168.

[5] Nangin, D dan A. Sutrisno. 2015. Amylase enzyme which breaks down raw starch from microbes. Jurnal pangan dan agroindustri. 3 (3) : 1032-1039.

[6] Ramansyah, M dan I. M. Sudiana. 2004. Optimization of amylase and glocokinase analysis extracted from Pleurotus ostreatus mycelium with 3,5 Dinitrosalicylic acid. Berk. Penel. Hayati. 9 : 7-12.

[7] Sadjad, S. 1993. From Seed To Seed. PT. Grasindo. Jakarta. Page :104-107.

[8] Salisbury and C. W. Ross. 1995. Physiology of Plant II. ITB. Bandung. Page: 11-14.

[9] Sari, L. D. A. 2004. Relationship of amylase enzyme activity with the germination of three different soybean varieties (Glycine max. L. Thesis. Biology Department). FMIPA. Universitas Diponegoro. Unpublished. Hal 25-26.

[10] Sopandie, D. 2014. Physiology of Plant Adaptation to Abiotic Stresses in Tropical Agroecosystems. IPB Press. Page: 78-131.Anggraini, Fita, Agus Suryanto, dan Nurul Aini. 2013. Sistem Tanam dan Umur Bibit Pada Tanaman Padi Sawah (Oryza sativa L.) Varietas Inpari 13. Jurnal Produksi Tanaman Vol.1 No.2. Universitas Brawijaya.

[11] Taiz, L dan E. Zeiger. 2006. Plant Physiology. Fourth Edition. Massachusetts (US): Inc Publisher. [downloaded at 11th December 2019].

[12] Tanaka, K. R., O. M. Miyazaki, Y. Ishibashi, T. Yuasa, and M. I. Inoue. 2009. Changes in NMR relaxation of rice grains, kernel quality and physicochemical properties in response to a high temperature after flowering in heatsensitive rice cultivars. Plant Prod Sci. 12:185-192. 
[13] Ying, C. Y., D. Hua, Y. L. Nian, W. Z. Qing, Z. S. Chuan and Y. J. Chang YJ. 2008. Effect of heat stress during meiosis on grain yield of rice cultivar differing in heat tolerance and its physiological mechanism. Acta Agron Sin. 34(12):2134-2142.

[14] Yoshida, S. 1978. Tropical climate and its influence on rice. Los Banos (PH): IRRI Res Pap Ser 20.

[15] Wahyuni. 2015. Enzymatic conversion testing of alphaamylase enzyme activity. Industrial Technology Faculty. Institut Teknologi Bandung. Bandung. 1-12.

[16] Wirahadikusumah. 1989. Biochemistry: Protein, Enzymes and Nucleic Acid Edition II. ITB. Bandung. Hal : 4369.Badan Litbang Pertanian. 2002. Pedoman pembentukan komisi daerah dan pengelolaan plasma nutfah. Badan Penelitian dan Pengembangan Pertanian, Deptan. 